О.В. Лезік, А.Ф. Волков, О.А. Токар, В.Г. Стадніченко

Харківський національний університет Повітряних Сил ім. І. Кожедуба, Харків

\title{
СУТНІСТЬ, ЗМІСТ ТА ОЦІНКА ЕФЕКТИВНОСТІ УПРАВЛІННЯ ПІДРОЗДІЛОМ ПРОТИПОВІТРЯНОЇ ОБОРОНИ СУХОПУТНИХ ВІЙСЬК ТА ВОГНЕМ В БОЮ
}

Розглядаються основні питання стосовно сутності та змісту управління, основ оцінки ефективності управління з метою вирішення певних завдань, а також можливості системи управління та визначаються основні фактори, від яких залежать можливості системи управління. Також визначений критерій ефективності та розроблені пропозищії щзодо підвищення ефективності управління підрозділом ППО СВ та вогнем в бою в різних умовах обстановки. Дані положення можуть бути використані для підвищення ефективності навчання курсантів факультету та тих, щзо навчаються на курсах підвищення кваліфікації, вдосконалення навчального процесу підготовки спеціалістів факультету, а також якості підготовки спеціалістів за фахом.

Ключові слова: управління, критерій, ефективність, підрозділ ППО СВ.

\section{Вступ}

Постановка проблеми. Головною вимогою на цей час $є$ підтримання бойової готовності підрозділів ППО СВ в такій мірі, яка дозволить уникнути раптовості удару засобів повітряного нападу ймовірного противника. У зв'язку з цім своєчасне розгортання й ефективне функціонування системи управління підрозділами ППО СВ стають вирішальними факторами, які забезпечують успіх у збройній боротьбі [1-2].

Рішення складного кола завдань управління підрозділами ППО СВ потребує наявності стрункої системи управління, наукової організації управлінської діяльності і застосування ефективних методів роботи командирів підрозділів ППО СВ.

Аналіз останніх досліджень і публікацій. У роботах [1-2; 16; 18-19] описано питання покращення системи управління, а також методи та способи, які дозволяють розглянути питання підвищення ефективності управління підрозділами в бою (діях). В останні часи, особливо при проведенні АТО, а зараз при проведенні операції об'єднаних сил (OOC), умови вирішення завдань управління значно ускладнились не тільки тому, що збільшилась потреба в якісному управлінні, що є необхідною умовою для ведення бою (дій) частинам і підрозділам ППО, а також тому, що умови ведення бою (дій) значно змінились [1]. Отже, виникає проблема дослідити систему управління з метою її удосконалення відповідними командирами, враховуючи сучасні потреби.

Мета статті. Комплекс проблем і питань, що визначають стан системи управління підрозділами ППО СВ, викликає необхідність наявності спеціального наукового апарату, який дозволяє оцінювати ефективність управління бою (дій) підрозділами ППО СВ та визначати шляхи ii удосконалення. Іншими словами, такий апарат повинен виробляти науково обгрунтовані практичні рекомендації, які базуються на об'єктивних законах (закономірностях) 3 використанням новітніх досягнень різних суміжних наук. Головне при цьому розкрити і розумно використовувати механізми прояви об'єктивних законів (закономірностей) в управлінні підрозділами ППО СВ, розробляти і застосовувати науково обгрунтовані принципи організації системи управління та методів роботи командування і штабів військ ППО СВ з широким використанням сучасних технічних засобів $[1-2 ; 16]$.

\section{Виклад основного матеріалу}

Уміння зосередити основні зусилля на головних напрямках багато в чому залежить від мистецтва управління силами і засобами, які є в наявності. Можна прямо стверджувати, що реалізація бойових можливостей підрозділів ППО СВ знаходиться в прямій залежності від ефективності управління ними. При добре організованій системі управління ступінь реалізації бойових можливостей підрозділів ППО СВ буде найбільш повною.

Розробка основ оцінки ефективності управління дозволить вирішити такі завдання.

По-перше, виявити ступінь відповідності системи управління законам управління і зростаючим вимогам до нього.

По-другє, визначити вплив рівня підготовленості особового складу органів управління на ефективність вирішення завдань управління.

По-третє, ще до проведення заходів по удосконаленню системи управління, структури і методів 
роботи органів управління оцінювати і прогнозувати їх раціональність.

По-четверте, визначити стан системи управління в цілому, а також іiі елементів 3 метою вироблення відповідних заходів по відновленню порушеного управління.

По-п'яте, робити порівняння своєї системи управління з системами управління ймовірних противників, що дозволить виявити слабкі місця і знайти способи захисту своєї системи управління і виведення з ладу систем управління противника.

Таким чином, одною і тою же кількістю активних вогневих засобів, в залежності від якості управління, можна досягти самого різного ступеня ураження противника. Цей надзвичайно важливий висновок для сфери управління військами привів до формування нового вимоги до управління військами - забезпечення високої ефективності використання бойових можливостей підрозділів ППО СВ [2].

Ефективність бою (дій) підрозділів ППО, які входять до системи ППО Сухопутних військ і ії основної складової частини - активних засобів, тобто зенітних підрозділів, як відомо, залежить від характеру дій повітряного противника, а також від ряду інших чинників [3]. Разом $з$ тим ефективність бою (дій) підрозділів ППО СВ багато в чому зумовлюється функціонуванням таких складових частин системи ППО, як система розвідки, система управління та інші системи, що забезпечують [4; 6].

У статті розглядається тільки вплив системи управління на систему ППО в цілому. Кореляційний зв'язок між системою управління і іншими системами, що забезпечують бій (діï) підрозділів ППО СВ в силу іiї складності і маловивченою не розглядається.

Розглянемо поняття ефективності бою (дій) підрозділів ППО СВ, тому що поняття ефективності управління підрозділами ППО СВ тісно пов'язано з цією ефективністю.

Як відомо, під ефективністю бойового застосування підрозділів ППО СВ в бою(діях) розуміється ступінь реалізації бойових можливостей підрозділів ППО СВ в бою (діях) в конкретних умовах обстановки, яка склалася [2; 10-14].

У цьому визначенні чітко виділяються два моменти.

По-перше, необхідно виявити бойові можливості сил або засобів, ефективність яких ми хочемо визначити.

По-друге, необхідно знайти показник, що характеризує ступінь реалізації наявних бойових можливостей у силах (засобах). Інакше кажучи, потрібно вибрати критерій ефективності.

Таким чином, спочатку потрібно конкретизувати поняття бойові можливості.

Змістом бойових можливостей підрозділів ППО СВ є властивості, здатність підрозділів і час- тин виконувати бойові завдання з урахуванням конкретних умов бойової обстановки.

Ступінь же реалізації бойових можливостей підрозділів ППО СВ оцінюється за критерієм математичного очікування числа знищених повітряних цілей, а кінцева мета дій підрозділів ППО СВ - за критерієм збереження бойового потенціалу військ, що прикриваються [5; 7-9].

Застосовуючи метод аналогій, можна сформулювати сутність поняття ефективності системи управління, не забуваючи про те, що ця система, як і інші системи, що забезпечують, безпосереднього бою (дій) не веде, але надає безпосередній вплив на ефективність вогневих засобів.

Під ефективністю системи управління будемо розуміти ступінь реалізації ії можливостей в інтересах забезпечення максимальних бойових можливостей підрозділів ППО СВ.

Оскільки в офіційних документах визначення поняття можливості системи управління відсутня, а $\epsilon$ визначення поняття бойові можливості системи ППО, то доцільно коротко розглянути їх співвідношення і взаємозв'язок.

Під бойовими можливостями системи ППО розуміється ії здатність виконувати бойове завдання зі знищення засобів повітряного нападу противника при витраті певних ресурсів за встановлений час в конкретних умовах обстановки.

Загальна здатність системи ППО виконувати бойові завдання залежить від здібностей підсистем виконувати свої приватні у відповідності за призначенням завдання. Наприклад, якщо система управління не забезпечить збір та обробку інформації, прийняття рішення і доведення завдань до військ, то система активних засобів і система ППО в цілому не буде здатною знищувати ЗПН противника.

Таким чином, бойові можливості системи ППО і можливості підсистем співвідносяться, як ціле і частина. Це означає, що бойові можливості системи ППО - це певна сукупність, комбінація можливостей підсистем.

За аналогією $з$ визначенням бойових можливостей системи ППО можна сформулювати поняття можливостей системи управління. Під можливостями системи управління будемо розуміти ії здатність виконувати певні функції (завдання) в складі системи ППО при витраті певних ресурсів за встановлений час в конкретних умовах обстановки.

Можливості системи управління, так само як i інших систем, і системи ППО в цілому - величини непостійні і змінюються в залежності від умов обстановки.

Основні фактори, від яких залежать можливості системи управління, можна умовно розділити на три групи: внутрішні, зовнішні і час.

До внутрішніх факторів належать, в першу чер- 
гу, ресурси і тактико-технічні характеристики елементів системи. Ресурси - це група чинників, що характеризують склад, стан і забезпеченість системи.

Під складом системи управління розуміється кількість органів управління в різних інстанціях, система зв'язку і засоби автоматизації.

Під станом розуміється рівень підготовки особового складу органів управління і технічного персоналу, злагодженість і взаємозамінність офіцерів штабу.

Забезпеченість характеризується укомплектованістю органів управління особовим складом, технікою, засобами зв'язку та автоматизації.

Максимальні можливості системи називають потенціалом системи.

Потенціал системи управління - це здатність системи виконувати покладені на неї функції (завдання) в складі системи ППО при витраті певних ресурсів за встановлений час.

Основна відмінність потенціалу від можливостей полягає в тому, що можливості системи управління визначаються для конкретних умов обстановки, а потенціал - безвідносно до вирішення на побудову системи ППО.

Разом з тим потенціал системи і їі можливості повинні оцінюватися при однакових значеннях ресурсу і за один і той же час

$$
\vec{q} \in q_{i} ; \quad t_{n} \leq t \leq t_{3},
$$

де $q_{i}-$ ресурси, якими володіє система;

$t_{n}$ - час початку бою (дій);

$t$ - час бою (дій);

$t_{3}-$ час закінчення бою (дій).

Потенціал системи в конкретних умовах обстановки перетворюється в їі можливості.

В подальшому будемо вживати термін „, система управління", розуміючи, що вона є підсистемою системи ППО.

3 матеріалу, що розглянуто можна зробити практичний висновок: система здатна виконувати покладені на неї функції (завдання) в межах своїх можливостей. В цьому випадку можна чекати високої ефективності системи.

Зовнішні фактори не є атрибутом системи. Вони визначають зовнішні умови, в яких функціонує система управління.

Аналіз завдань, що вирішуються системою управління, показує, що процес їх вирішення здійснюється циклічно. При цьому чітко проявляються три головні моменти циклу:

- збір даних обстановки;

- вироблення рішення;

- доведення завдань до підрозділів.

Рішення будь-якого із завдань управління, здійснюваних в контурі управління, зводиться в кінцевому підсумку до трьох позицій циклу управління. При цьому реалізація таких найважливіших вимог, як оперативність і якість управління на всіх етапах циклу управління повинна оцінюватися комплексно, але 3 врахуванням пріоритетності кожної з цих вимог.

Отже, можна зробити висновок: можливості системи управління найбільш доцільно оцінювати 3 позиції реалізації циклу.

Оскільки поставлене завдання завжди має кількісну міру, то і здатність виконати це завдання, тобто можливості системи, пов'язана 3 кількісною мірою. Отже, можливості системи управління необхідно оцінювати кількісно.

Зазвичай при підготовці бою (дій) можливості системи управління оцінюються прогнозованим результатом іiі впливу на бій (дії) підрозділів ППО СВ, які входять до системи ППО.

3 наведених вище визначень ефективності i можливостей системи управління можна зробити ряд важливих практичних висновків [2].

По-перше, ефективність - поняття більш загальне, ніж бойові можливості, так як передбачає їх порівняння з поставленими завданнями.

По-друге, можливості показують, який обсяг завдань здібна виконати система, а ефективність показує, наскільки цей обсяг завдань відповідає поставленим цілям.

По-третє, ефективність по відношенню до бойових можливостей $\epsilon$ величиною відносною. Це узгоджується 3 тим, що можливості характеризуються результатом бою (дій). Стосовно до системи управління це позначається на ступені ії впливу на бій (дії) активних засобів системи ППО.

Таким чином, ефективність - це результаттивність, тобто відносний результат.

По-четверте, можливості - категорія, якою користуються до початку бою (дій), а ефективність може бути як прогнозованою (і тоді вона кількісно в однакових умовах буде дорівнювати можливостям), так і реально досягнутою. В останньому випадку про ефективність судять за вкладом системи управління в реальний результат бою (дій).

По-п'яте, і бойові можливості і ефективність системи повинні оцінюватися при одних і тих же умовах, тобто при витраті певних ресурсів за встановлений час, в конкретних, однакових умовах обстановки.

Розглянуті висновки дозволяють встановити співвідношення між можливостями та ефективністю системи управління. Можливості показують, що здатна зробити система, а ефективність - наскільки це відповідає поставленим цілям.

Одним з ключових принципів оцінки ефективності управління $\epsilon$ застосування методології системного підходу.

Відповідно до цього принципу система управ- 
ління, по-перше, розглядається як ієрархічна структура від вищих ланок до нижчих і, по-друге, система управління кожної ланки управління - як підсистема управління системи вищої інстанції.

Іншим принципом оцінки ефективності $є$ вибір вкладу системи управління в досягнення кінцевої мети бою (дій). При реалізації цього принципу не можна забувати про те, що дуже важко висловити числом частку або ступінь впливу управління в успіх чи неуспіх бою (дій) угруповання ППО, відокремивши управління від інших факторів.

Таким чином, абсолютна ефективність системи управління важко піддається оцінці. Тому в практичній діяльності необхідно шукати іншу міру внеску для оцінки ефективності управління.

Таким заходом може служити розподіл ефективності на внутрішню і зовнішню.

Ефективність системи управління в цілому може оцінюватися за сукупністю показників внутрішньої і зовнішньої ефективності при визначальній ролі останньої.

Внутрішня ефективність дозволяє оцінювати систему управління з точки зору виконання нею завдань управління.

Для конкретної оцінки впливу зовнішньої ефективності управління на бій(діiі) угруповання військ ППО необхідні кількісні показники.

Оцінка внутрішньої ефективності системи управління може здійснюватися за допомогою наступної групи критеріїв. Перша група буде характеризувати оцінку складових елементів системи управління. До другої групи можна віднести критерії, що дозволяють оцінити систему управління в цілому. Для оцінки зовнішньої ефективності системи доцільно використовувати інші критерії. Певна група критеріїв має характеризувати вплив системи управління на ефективність дії активних засобів ППО.

Інша група критеріїв характеризує цільову функцію системи ППО, тобто кінцеву мету, яка, як відомо, міститься в цілісності бойового потенціалу прикриваються військ за рахунок бою (дій) підрозділів ППО СВ.

Інший підхід до вибору системи критеріїв пов’язаний з оцінкою внутрішньої ефективності системи управління через відповідність висунутих до неї вимог з бойової готовності, оперативності, високій якості, стійкості, безперервності і скритності в роботі.

Система управління може оцінюватися за різними показниками. Однак найбільш доцільно 3 точки зору обробки інформації оцінювати іï 3 позиції реалізації циклу управління.

Основними показниками циклу управління $€$ часові витрати (оперативність) і якість.

Часові витрати на цикл управління характери- зують систему управління 3 точки зору оперативності іiі функціонування, тобто здібності командирів та органів управління вирішувати завдання в режимі часу, що забезпечує попередження в діях противника. Отже, необхідно, щоб система управління забезпечувала постійний позитивний баланс часу, який виражається наступною нерівністю

$$
T_{\mathrm{y}}^{\mathrm{L}}+T_{\partial} \leq T_{\text {крum }},
$$

де $T_{\mathrm{y}}^{Ц}$ час, що витрачається на процеси циклу управління;

$T_{\text {в }}$ - час виконання підрозділами отриманих команд;

$T_{\text {крит }}$-час, після закінчення якого дії підрозділів не приведуть до вирішення завдання (ураження повітряних цілей противника).

У тих випадках, коли окремі процеси циклу управління можна вважати строго детермінованими, тобто визначеними, то вираз спрощується до виду

$$
T_{\phi} \leq T_{\text {дup }},
$$

де $T_{\phi}$ - час, який фактично витрачається на проведення заходу управління;

$T_{\partial u p}-$ встановлений (директивний) час.

Це можливо, наприклад, при проведенні тренувань по підняттю частини по бойовій тривозі. Однак слід зазначити, що в найбільш загальному вигляді процеси приведення підрозділів (частин) у бойову готовність носять імовірнісний характер так само, як і всі інші процеси управління.

Набагато складніше йде справа 3 оцінкою якості процесів управління. Перш за все необхідно відзначити, що оперативність і якість процесів управління необхідно розглядати тільки в тісній єдності і взаємодії. Не все те, що зроблено швидко буде якісним. Тому, аналізуючи будь-який процес управління або заходи з точки зору часових показників, не можна забувати і про якісні показники.

Співвідношення між показниками оперативності і якості не однозначні в кожному управлінському процесі, але завжди тісно пов'язані.

При прийнятті рішення головним показником виступає якість. Одним 3 методів оцінки якості прийнятих рішень може служити кількість розглянутих i обгрунтованих розрахунками варіантів рішення в обмежені терміни. При доведенні завдань до військ визначальним показником $є$ час. Однак i тут необхідно враховувати якість цього процесу за повнотою, своєчасністю, скритністю й іншими показниками.

Таким чином, оцінюючи систему управління в цілому за критеріями оперативності і якості, необхідно в кожному конкретному процесі враховувати міру їх важливості.

У групі критеріїв, які використовуються для 
оцінки зовнішньої ефективності, найбільш доцільно вибрати в якості основного математичне очікування числа знищених ЗПН противника. Саме цей критерій найбільшою мірою відображає сутність боротьби засобів протиповітряної оборони 3 повітряним противником.

Як відомо, ефективність ППО є функцією великої кількості факторів. У загальному плані це можна виразити наступною залежністю

$$
E=f(t, \vec{q}, \vec{A}, \vec{B}, \vec{C})
$$

де $t$ - час;

$\vec{q}$ - ресурси;

$\vec{A}$ - технічні характеристики системи;

$\vec{B}$ - оперативно-тактичні $\quad$ характеристики системи;

$\vec{C}-$ зовнішні умови.

Існує ряд методик, за допомогою яких можна розрахувати МОЧ числа знищених ЗПН противника. У цих методиках вплив управління зазвичай враховується коефіцієнтом, який представляє собою внутрішню ефективність системи управління.

Група критеріїв, що характеризує зовнішню ефективність системи управління, дозволяє здійснити розрахунок цільової функції системи, під якою розуміється математичний вираз такого результату функціонування системи в певних умовах обстановки, який виражає ступінь досягнення поставленої перед системою мети. Такою кінцевою метою для системи ППО є ступінь збереження бойового потенціалу прикриваємих підрозділів за рахунок бою (дій) підрозділів ППО СВ.

У загальному плані збиток, що наноситься підрозділам, що прикриваються, можна визначити за виразом

$$
U_{\mathrm{H}}=U_{B}-U_{c},
$$

де $U_{\mathrm{H}}-$ збиток, що наноситься військам, які прикриваються;

$U_{B}$ - можливості противника по нанесенню втрат військам, які прикриваються;

$U_{3}-$ зниження шкоди за рахунок дій військ ППО.

Аналізуючи цей вислів, неважко помітити, що чим більше буде величина тим менше буде збиток, що наноситься повітряним противником підрозділам, що прикриваються. Отже, тим більше буде збережений бойовий потенціал підрозділів, що прикриваються. А оскільки втрати повітряного противника визначаються з урахуванням впливу системи управління через математичне очікування числа знищуваних повітряних цілей, то можна визначити i ступінь впливу системи управління на цільову функцію системи ППО - збереження бойового потенціалу підрозділів, що прикриваються.
При розгляданні методів оцінки ефективності системи управління військами ППО доцільно враховувати, що у складній і багатопланової області діяльності, якою є управління, не всі його показники можуть бути виражені числом, отриманим в результаті експерименту або розрахунку. Велике значення мають і суто логічні побудови, на основі яких можна отримати ту чи іншу кількісну оцінку різних, особливо якісних показників системи управління. Крім того, не всякий показник, що відноситься до управління військами, може бути віднесений до критеріїв його ефективності.

Оцінку ефективності системи управління можна здійснювати різними методами.

Так, досліджуючи функціонування систем управління в бойових діях у Другий Світовій війні, післявоєнних збройних конфліктах, можна отримати ряд кількісних показників, що характеризують внутрішню ефективність системи управління. Сучасний підхід до оцінки ефективності управління базується на широкому застосуванні фізичного, математичного або комбінованого методів моделювання бою (дій) [15-16]. Застосування цих методів, особливо методу математичного моделювання, дозволяє здійснювати прогнозування бою (дій), які відбудуться і на цій основі визначати показники зовнішньої і внутрішньої ефективності управління, проводити порівняльну оцінку різних варіантів системи управління і вибирати з них раціональний.

Фізичне моделювання бою (дій), тобто багатократне проведення навчань та стрільб, є відносно надійним методом отримання інформації для оцінок ефективності різних систем управління підрозділів ППО СВ. Однак потрібно враховувати, що при проведенні навчань і стрільб допускається багато умовностей. Крім того, для отримання досить стійких результатів необхідно проводити велику кількість навчань, що дуже дорого. Тому метод математичного моделювання найбільш економічний і потребує менше часу [15-17].

Розрізняють два основні методи математичного моделювання: статистичний і аналітичний.

За останні роки отримав розвиток новий напрямок пошуку способів автоматизованого вирішення складних завдань евристичним методом. Сутність його полягає у виявленні принципів діяльності посадових осіб органів управління при вирішенні ними завдань управління. Коротко нагадаємо i метод експертних оцінок. Він використовується в тих випадках, коли іншими способами (розрахунком, експериментом тощо) отримати необхідні дані не вдається.

Всі зазначені методи оцінки ефективності системи управління можуть бути використані для отримання часткових і інтегральних показників, а також для оцінки іiі внутрішньої і зовнішньої ефектив- 
ності.

Розглянемо деякі можливі методики оцінки ефективності системи управління військами. При розробці таких методик будемо виходити з наступних положень [2].

По-перше, оскільки ефективність системи управління, як було показано вище, є ступінь реалізації можливостей системи при витраті певних ресурсів за встановлений час в конкретних умовах обстановки, то перш за все необхідно визначити критерії оцінки можливостей системи.

По-друге, оцінку системи управління доцільно здійснювати через цикл управління. Отже, необхідно визначити можливості системи на кожному етапі циклу.

По-третє, оскільки при підготовці бою (дій) всі завдання управління прогнозуються, то й ступінь їх виконання повинна оцінюватися імовірностними величинами.

Виходячи 3 цих положень, розглянемо можливий підхід до оцінки ефективності системи управління. Цикл управління починається з рішення задач збору, обробки і зберігання інформації про противника, своїх військах і умовах, в яких буде вестися бій (діі).

Кожне 3 цих завдань визначається можливостями різних засобів розвідки та інших джерел інформації. Позначимо ймовірність вирішення цього комплексу завдань $P_{3 б}$.

Зібрана інформація, природно, повинна бути своєчасною, повною й з заданою імовірністю доставлена до пункту управління. Позначимо ймовірність вирішення цього завдання $P_{\text {д }}$.

Другий етап циклу - вироблення пропозицій щодо прийняття рішення на організацію ППО в майбутньому бою (діях). Це є центральним моментом, тому що рішення $\epsilon$ основою управління. Визначимо ймовірність виконання органом управління завдань 3 вироблення оптимального рішення в задані терміни $P_{\mathrm{p}}$.

Нарешті, третій етап циклу управління полягає в доведені завдань до підлеглих. В цьому етапі вирішуються дві основні задачі: підготовка необхідних документів і їх передача виконавцям з використанням засобів зв'язку. Позначимо ймовірності вирішення цих завдань через $P_{\text {док }}$ і $P_{\text {дост }}$. Очевидно, що $P_{\text {дост }}$ і $P_{\text {д }}$ (при доставці інформації на пункти управління) рівні, бо обидві ймовірності характеризують можливості системи і засобів зв'язку.

Оскільки цикл управління складається в сумісному вирішенні зазначених завдань, можна використовувати теорему множення ймовірностей. При цьому необхідно враховувати, що рішення кожного подальшого завдання визначається умов- ною ймовірністю рішення попереднього завдання. Наприклад, ймовірність прийняття рішення залежить від імовірності рішення завдання збору даних обстановки.

Таким чином, ймовірність виконання циклу управління в допущений час, який залежить від противника, або в задані вищим органом управління терміни може бути представлена у вигляді наступного виразу

$$
P_{\text {ц }}=P_{\text {зб }} P_{\mathrm{p}}\left(P_{\text {зб }}\right) P_{\text {док }}\left(P_{\mathrm{p}}\right) P_{\text {д }},
$$

де $P_{\text {IL }}$-ймовірність виконання циклу управління у визначений час;

$P_{36}$-ймовірність вирішення завдань зі збору необхідної інформації;

$P_{\mathrm{p}}$-ймовірність виконання органом управління завдань 3 вироблення оптимального рішення в задані терміни;

$P_{\text {док }}-$ ймовірність підготовки необхідних документів;

$P_{\text {дост }}-$ ймовірність доставки необхідних документів виконавцям з використанням засобів зв'язку.

Кожна 3 розглянутих ймовірностей розподіляється по своєму закону. Згідно центральній граничній теоремі теорії ймовірностей можна 3 достатньою підставою вважати, що розподіл часу виконання всіх завдань циклу управління підпорядковується нормальному закону, до якого наближаються всі інші закони розподілу при типових умовах, які часто зустрічаються.

При розгляданні методики оцінки ефективності системи управління підрозділів ППО СВ доцільно вважати, що основу системи управління, як відомо, складають органи і пункти управління, система зв'язку i АСУВ. Оскільки всі ці елементи зосереджені на командному пункті, то це дозволяє 3 деякими припущеннями розглядати систему управління як сукупність взаємопов'язаних між собою командних пунктів. Тоді оцінку внутрішньої ефективності системи управління $E_{\mathrm{Cy}}$ можна звести до оцінки ефективності системи командних пунктів управління $E_{\mathrm{C}_{\text {KП }}}$, тобто

$$
E_{\mathrm{Cy}} \approx E_{\mathrm{C}_{\mathrm{K \Pi}}} \text {, }
$$

де $E_{\mathrm{Cy}}-$ внутрішня ефективність системи управління;

$E_{\mathrm{C}_{\text {KП }}}$-ефективність системи управління командних пунктів.

При цьому цілком очевидно, що ефективність системи командних пунктів зумовлюється ефективністю БКП (ПУ), які входять до їх складу:

$$
E_{C_{K \Pi}}=f\left(E_{\mathrm{K}_{1}}, \ldots, E_{\mathrm{K}_{i}}, \ldots, E_{\mathrm{K}_{n}}\right) .
$$

В якості критеріїв, які найбільшою мірою хара- 
ктеризують функціонування командних пунктів, можуть бути кількісно-якісна характеристика особового складу органу управління $W$ і оснащеність пункту управління технічними засобами управління $Z^{1}$.

Таким чином, ефективність системи управління може бути представлена функцією

$$
E_{\mathrm{K} \Pi}^{B H}=f(W, Z) .
$$

У свою чергу, кількісно-якісна характеристика особового складу командного пункту $є$ функцією ступеня укомплектованості особовим складом $X$ i рівня якості його підготовки $Y$ :

$$
W=f(X, Y) .
$$

Величини $X$ i $Z$ визначаються за формулами:

$$
X=\frac{X_{\mathrm{o} . \mathrm{c}}^{\mathrm{p}}}{X_{\mathrm{o} . \mathrm{c}}^{\amalg}} ; \quad Z=\frac{Z_{\mathrm{T} .3}^{\mathrm{p}}}{Z_{\mathrm{T} .3}^{\amalg}},
$$

де $X_{\text {o.c }}^{p}$ - реальна кількість особового складу КП;

$X_{\text {o.c }}^{u}$ - штатна кількість особового складу КП;

$Z_{\text {т.3 }}^{p}$ - реальна кількість технічних засобів;

$Z_{\text {т.3 }}^{u}$ - штатна кількість технічних засобів.

Найбільші, труднощі виникають при кількісній оцінці рівня якості підготовки особового складу командного пункту. Ці труднощі обумовлені багатокритериальністю об'єкта оцінки. Тому в даній методиці для спрощення оцінки якості підготовки особового складу командного пункту обрані два показника:

$K_{a}$ - відносна кількість офіцерів органу управління, які закінчили військовий заклад (наприклад, академію) (\%), що характеризує рівень теоретичної підготовки;

$K_{\Pi}-$ відносна кількість офіцерів органу управління, що мають стаж на займаній посаді не менше 2,5 років (\%), що характеризує рівень практичної підготовки.

Припустимо, що підготовленість особового складу командного пункту, який пропрацював на посаді менше 2,5 років і не має академічної освіти, буде в два рази нижче ідеальної. Тоді для оцінки якості підготовки особового складу командного пункту тактичного звена управління можна використовувати наступну емпіричну залежність

$$
Y=\frac{30}{200-K_{a}}+\frac{70}{200-K_{n}} .
$$

Маючи чисельні значення ступеня укомплектованості та якості підготовки особового складу командного пункту, можна визначити кількісно-якісну характеристику особового складу органу управління

$$
W=X \times Y .
$$

Тоді ефективність командного пункту буде дорівнювати

$$
E_{\mathrm{K \Pi}}=W \times Y .
$$

Ефективність системи командних пунктів, а значить й системи управління в цілому, визначається за допомогою „вагової” згортки критеріїв ефективності конкретних БКП (ПУ), які входять до їі складу:

$$
E_{C y}=\sum_{i=1}^{N} E_{C y} \cdot G_{i},
$$

де $G_{i}-$ вклад $i$-го КП (ПУ) в рішення завдань системою управління (при цьому $\sum_{i=1}^{N} G_{i}=1$ );

$N$ - загальна кількість КП (ПУ) в складі системи управління.

В даний час існують різні способи визначення значень коефіцієнтів $G_{i}$. Одним 3 них є спосіб обробки результатів експертного опитування.

Оцінка впливу системи управління на ефективність угруповання військ ППО може бути здійснена різними методами і зокрема застосуванням математичної моделі бою (дій) підрозділів ППО СВ.

\section{Висновки}

Отже, можна зробити висновок: можливості системи управління найбільш доцільно оцінювати 3 позиції реалізації циклу. Так як система управління складається з підсистем (органи управління, пункти управління, АСУВ, зв'язку та інші спеціальні підсистеми), то для визначення можливостей системи управління в цілому необхідно вміти визначати i можливості їі підсистем.

Оскільки поставлене завдання завжди має кількісну міру, то і здатність виконати це завдання, тобто можливості системи, пов'язана 3 кількісною мірою. Отже, можливості системи управління необхідно оцінювати кількісно.

Зазвичай при підготовці бою (дій) можливості системи управління оцінюються прогнозованим результатом іiі впливу на бій (дії) підрозділів ППО СВ, які входять до системи ППО.

Для кількісної оцінки можливостей застосовуються різні показники (критерії). Для чіткого розуміння питання про показники (критерії), які використовуються для оцінки можливостей i ефективності системи управління, необхідно виявити зв'язок цих понять.

3 наведених вище визначень ефективності та можливостей системи управління можна зробити ряд важливих практичних висновків.

По-перше, ефективність - поняття більш загальне, ніж бойові можливості, так як передбачає їх порівняння з поставленими завданнями.

По-друге, можливості показують, який обсяг 
завдань здібна виконати система, а ефективність показує, наскільки цей обсяг завдань відповідає поставленим цілям.

По-третє, ефективність по відношенню до бойових можливостей є величиною відносною. Це добре узгоджується 3 тим, що можливості характеризуються ефектом, тобто результатом бою (дій). Стосовно до системи управління це позначається на ступені їі впливу на бій (дії) активних засобів системи ППО.

Таким чином, ефективність - це результативність, тобто відносний результат.

По-четверте, можливості - категорія, якою користуються до початку бою (дій), а ефективність може бути як прогнозованою (і тоді вона кількісно в однакових умовах буде дорівнювати можливостям), так і реально досягнутою. В останньому випадку про ефективність судять за вкладом системи управління в реальний результат бою (дій).

По-п'яте, i бойові можливості і ефективність системи повинні оцінюватися при одних і тих же умовах, тобто при витраті певних ресурсів за встановлений час, в конкретних, однакових умовах обстановки. Інакше кажучи, ефективність залежить від тих же факторів, що і можливості [2].

Розглянуті висновки дозволяють встановити співвідношення між можливостями та ефективністю системи управління. Можливості показують, що здатна зробити система, а ефективність - наскільки це відповідає поставленим цілям.

\section{Список літератури}

1. Алімпієв А.М. Особливості гібридної війни РФ проти України. Досвід, що отриманий Повітряними Силами Збройних Сил України / А.М. Алімпієв, Г.В. Пєвцов // Наука і техніка Повітряних Сил Збройних Сил України. - 2017. - № 2(27). - C. $19-25$.

2. Управление войсками ПВО Сухопутных войск. Части 1,2 / Б.И. Хабаров, И.Ф. Оленович, В.А. Муренко и др.; под ред. Ю.Т. Чеснокова - К.: ВА ПВО СВ, 1990. - 392 с.

3. Підвищення ефективності прикриття вибухонебезпечних об'єктів за рахунок сумісного застосування тактиковогневих підрозділів ППО і тактико-спеціальних підрозділів РЕБ / О.В. Лезік, С.В. Орєхов, Г.А. Левагін, Д.В. Книш // Наука і техніка Повітряних Сил Збройних Сил України. - 2018. - № 2(31). - С. 167-173.

4. Забезпечення бойових дій підрозділів військ ППО СВ. Частина 1. Бойове та тилове забезпечення бойових дій підрозділів військ ППО СВ / С.В. Орєхов, С.В. Ворошилов, О.В. Лезік та ін.; за ред. С.В. Орєхова. - Х.: ХУПС, 2012. - 287 с.

5. Лезік О.В. Розробка пропозицій щодо раціонального бойового застосування сумісних дій підрозділів ППО та РЕБ під час проведення АТО / О.В. Лезік, С.С. Рязанцев, Д.В. Книш // Наука і техніка Повітряних Сил Збройних Сил України. 2015. - № 4(21). - С. 18-20.

6. Забезпечення бойових дій підрозділів військ ППО СВ. Частина 2. Технічне забезпечення бойових дій підрозділів військ ППО СВ / С.В. Орєхов, С.М. Піскунов, Г.В. Акулінін та ін.; за ред. С.В. Ворошилова. - Х.: ХУПС, 2011. - 203 с.

7. Сухаревський О.І. Оцінювання параметрів зон виявлення безпілотного літального апарату “Орлан-10” радіолокаційними засобами самохідного зенітного ракетного комплексу 9К33М3 “Оса-АКМ” / О.І. Сухаревський, В.О. Василець, I.Є. Ряполов // Наука і техніка Повітряних Сил Збройних Сил України. - 2016. - № 4(25). - С. 33-38.

8. Оцінка характеристик вторинного випромінювання масштабної моделі багатоцільового вертольота МI-8МТ, отриманої при проведенні вимірювань у безлунній камері / О.І. Сухаревський, В.О. Василець, І.Є. Ряполов, М.М. Бречка // Системи обробки інформації. - 2017. - № 1(147). - С. 109-114.

9. Al-Subhi A. Aplication of the AHP in Project Management/ Al-Subhi Al-harbi, M. Kamal // International Jornal of Project Management. - 2001. - Vol. 19. - P. 19-27.

10. Бойовий статут військ ППО СВ. Частина 3 (взвод, відділення, обслуга). - К.: КСВ ЗС України, 2016. - С. 11-25.

11. Дробаха Г.А. Взаємодія тактико-вогневих підрозділів зенітних ракетних військ та протиповітряної оборони сухопутних військ при вирішенні завдань протиповітряної оборони / Г.А. Дробаха, Б.А. Генов, Г.М. Зубрицький // Наука і техніка Повітряних Сил Збройних Сил України. - 2014. - № 1(14). - С. 90-93.

12. Бойове застосування зенітних ракетних батарей, озброєних зенітним ракетним комплексом “Оса-АКМ” / С.В. Орєхов, О.В. Лезік, В.І. Самоквіт та ін.; за ред. С.В. Орєхова. - Х.: ХУПС, 2010. -216 с.

13. Визначення важливості характеристик зенітного ракетного комплексу / С.П. Ярош, В.В. Шулежко, А.К. Зимницький, П.О. Степанов // Наука і техніка Повітряних Сил Збройних Сил України. - 2015. - № 1(18). - С. 54-60.

14. Порівняльне оцінювання зенітних ракетних комплексів методом перевірки відповідності їх тактико-технічних характеристик оперативно-тактичним вимогам / С.П. Ярош, К.В. Закутін, В.В. Воронін, В.В. Шулежко // Наука і техніка Повітряних Сил Збройних Сил України. - 2015. - № 3(20). - С. 85-91.

15. Городнов В.П. Моделирование боевых действий частей, соединений и объединений Войск ПВО / В.П. Городнов. Х.: ВИРТА, 1987. $-380 \mathrm{c}$.

16. Єрмошин М.О. Оцінка ефективності бойових дій зенітних ракетних військ / М.О. Єрмошин, Г.А. Дробаха. - Х.: XВУ, 2004. $-259 \mathrm{c}$.

17. Луцишин А.М. Проблеми визначення управління протиповітряною обороною під час проведення операції збройних сил / А.М. Луцишин, Г.С. Степанов, І.А. Костюк // Системи управління, навігації та зв'язку. - 2018. - № 47. - С. 52-58.

18. Волков А.Ф. Критерії оцінювання ефективності організації взаємодії під час ведення протиповітряної оборони військ / А.Ф. Волков, О.А. Яненко, С.А. Кравченко // Збірник наукових праць Харківського національного університету Повітряних Сил. - 2019. - № 3(61). - С. 7-11.

19. Тактичне мистецтво військ Протиповітряної оборони Сухопутних військ та його розвиток за досвідом сучасних збройних конфліктів / А.Ф. Волков, О.В. Лезік, К.М. Горбачев, С.М. Базіло // Збірник наукових праць Харківського національного університету Повітряних Сил. - 2019. - № 4(64). - С. 40-45. 


\section{References}

1. Alimpiev, A.N. and Pevtsov, G.V. (2017), "Osoblivosti gibridnoi viyni RF proty Ykrainy. Dosvid, otrymanyi Povitryanymy Sylamy Zbroynyh Syl Ykrainy" [The features of the hybrid war of the Russian federation against Ukraine. Experience received by the armed forced of the forced of Ukraine], Science and Technology of the Air Force of Ukraine, No. 2(27), pp. 19-25.

2. Habarov, B.I., Olenovich, I.F. and Myrenko, V.A. (1990), "Ypravlenie voiskami PVO Syhopytnih voisk. Casti 1,2. a manual" [Troop control of units of air defense units], VA PVO SV, Kyiv, 392 p.

3. Lezik, O.V., Oriekhov, S.V., Levahin, H.A. and Knysh, D.V. (2018), "Pidvyshchennia efektyvnosti prykryttia vybukhonebezpechnykh obiektiv za rakhunok sumisnoho zastosuvannia taktyko-vohnevykh pidrozdiliv PPO i taktyko-spetsialnykh pidrozdiliv REB" [Increasing the effectiveness of the coverage of explosive objects due to the joint use of tactical and fire subdivisions of air defense and tactical and special units of electronic warfare], Science and Technology of the Air Force of Ukraine, No. 2(31), pp. 167-173.

4. Oriekhov, S.V., Voroshilov, S.V. and Lezik, O.V. (2012), "Bojove ta tylove zabezpecennya boyevyh diy pidrozdiliv viysk PPO SV" [Technical support for combat operations of units of air defense units], KHUPS, Kharkiv, $287 \mathrm{p}$.

5. Lezik, O.V., Riazantsev, S.S. and Knysh, D.V. (2015), "Rozrobka propozytsii shchodo ratsionalnoho boiovoho zastosuvannia sumisnykh dii pidrozdiliv PPO ta REB pid chas provedennia ATO”, [Development of proposals for the rational combat use of joint actions of air defense and EW units during the anti-terrorist operation], Science and Technology of the Air Force of Ukraine, No. 4(21), pp. 18-20.

6. Oriekhov, S.V., Piskynov, S.M. and Akylinin, G.V. (2011), “Technicne zabezpecennya boyevyh diy pidrozdiliv viysk PPO $S V^{\prime}$ ' [Technical support for combat operations of units of air defense units], KHUPS, Kharkiv, $203 \mathrm{p}$.

7. Sukharevskyi, O.I., Vasylets, V.O. and Riapolov, I.Ye. (2016), "Otsiniuvannia parametriv zon vyiavlennia bezpilotnoho litalnoho aparatu "Orlan-10" radiolokatsiinymy zasobamy samokhidnoho zenitnoho raketnoho kompleksu 9K33M3 "Osa-AKM"” [The estimation of parameters of the detection zones of the UAV "Orlan-10" radar equipment self-propelled anti-aircraft missile system 9K33M3 "Osa-AKM"], Science and Technology of the Air Force of Ukraine, No. 4(25), pp. 33-38.

8. Sukharevskyi, O.I., Vasylets, V.O., Riapolov, I.Ye. and Brechka, M.M. (2017), "Ocinka harakteristik vtorinnogo viprominyuvannya masshtabnoyi modeli bagatocilovogo vertolota MI-8MT, otrimanoyi pri provedenni vimiryuvan u bezlunnij kameri" [Scattering characteristics of Mi-8MT helicopter based on measurements of object scale model in an anechoic chamber], Information Processing Systems, No. 1(147), pp. 109-114.

9. Al-Subhi, Al-harbi (2001), Aplication of the AHP in Project Management, International Jornal of Project Management, No. 19. - P. 19-27.

10. The Armed Forces of Ukraine (2016), "Boyovyi statyt viysk PPO SV. Chastyna 3 (vzvod, viddilennya, obslyga" [The combat status of the troops air defense of SF (platoon, department, service)], Kyiv, pp. 11-25.

11. Drobakha, H.A., Henov, B.A. and Zubrytskyi, H.M. (2014), "Vzaiemodiia taktyko-vohnevykh pidrozdiliv zenitnykh raketnykh viisk ta protypovitrianoi oborony sukhoputnykh viisk pry vyrishenni zavdan protypovitrianoi oborony" [Interaction of tactical and fire units of anti-aircraft missile forces and air defense of the ground forces in solving air defense tasks], Science and Technology of the Air Force of Ukraine, No. 1(14), pp. 90-93.

12. Oriekhov, S.V., Lezik, A.V. and Samokvit, V.I. (2010), "Boyove zastosyvannya zenitnych raketnych batarey, ozbroenych zenitnym raketnym komplechsom "OSA-AKM" [Fighting the use of anti-aircraft missile batteries armed with the "OSA-AKM" anti-aircraft missile system], KHUPS, Kharkiv, 216 p.

13. Yarosh, S.P., Shulezhko, V.V., Zymnytskyi, A.K. and Stepanov, P.O. (2015), "Vyznachennia vazhlyvosti kharakterystyk zenitnoho raketnoho kompleksu" [Determination of importance of specification antiaircraft missile system], Science and Technology of the Air Force of Ukraine, No. 1(18), pp. 54-60.

14. Yarosh, S.P., Zakutin, K.V., Voronin, V.V. and Shulezhko, V.V. (2015), "Porivnialne otsiniuvannia zenitnykh raketnykh kompleksiv metodom perevirky vidpovidnosti yikh taktyko-tekhnichnykh kharakterystyk operatyvno-taktychnym vymoham" [Comparative estimation of antiaircraft rocket complexes method of check of their conformity tactical and technical characteristics to operational and tactical requirements], Science and Technology of the Air Force of Ukraine, No. 3(20), pp. 85-91.

15. Gorodnov, V.P. (1987), "Modelirovanie boevych deystviy chastey, soedineniy i obedineniy viysk PPO" [Simulation of combat operation of units, formations of air defense forces], VIRTA, Kharkiv, $380 \mathrm{p}$.

16. Yermoshyn, M.O. and Drobakha, G.A. (2004), "Ozinka efektivnosti boiovich diy zenitnych raketnych viysk" [Estimation of the effectiveness of combat operations of anti-aircraft missile troops], KHVU, Kharkiv, $259 \mathrm{p}$.

17. Lutsyshyn, A.M., Stepanov, G.S. and Kostiuk, I.A. (2018), "Problemy vyznachennya upravlinnya protypovitryanoy oboronoy pid chas provedennya operaciu zbroinyh syl. Systemy upravlinnya, navigacii ta zvyazku" [Problems of definition of air defense control during the operation of the armed forces. Systems of control, navigation and communication], Collection of Scientific Works, No. 47, pp. 52-58.

18. Volkov, A.F., Yanenko, O.A. and Kravchenko, S.A. (2019), "Kryterii otsiniuvannia efektyvnosti orhanizatsii vzaiemodii pid chas vedennia protypovitrianoi oborony viisk" [Criteria for assessing the effectiveness of the organization of interaction during the air defense of troops], Scientific Works of Kharkiv National Air Force University, No. 3(61), pp. 7-11. https://doi.org/10.30748/zhups.2019.61.01.18.

19. Volkov, A.F., Lezik, O.V., Horbachov, K.M. and Bazilo, S.M. (2019), "Taktychne mystetstvo viisk Protypovitrianoi oborony Sukhoputnykh viisk ta yoho rozvytok za dosvidom suchasnykh zbroinykh konfliktiv" [Tactical art of Air Defense forces Ground forces and its development from the experience of modern armed conflicts], Scientific Works of Kharkiv National Air Force University, No. 4(62), pp. 40-45. https://doi.org/10.30748/zhups.2019.62.05. 
Відомості про авторів:

Лезік Олександр Віталійович

кандидат військових наук доцент

доцент кафедри

Харківського національного університету

Повітряних Сил ім. І. Кожедуба,

Харків, Україна

https//orcid.org/0000-0002-7186-6683

Волков Андрій Федорович

начальник кафедри

Харківського національного університету

Повітряних Сил ім. I. Кожедуба,

Харків, Україна

https//orcid.org/0000-0003-4529-261X

Токар Олександр Анатолійович

старший викладач кафедри

Харківського національного університету

Повітряних Сил ім. I. Кожедуба,

Харків, Україна

https//orcid.org/0000-0003-4889-7550

Стадніченко Володимир Григорович

заступник начальника кафедри

Харківського національного університету

Повітряних Сил ім. І. Кожедуба,

Харків, Україна

https//orcid.org/0000-0002-1780-9215
Information about the authors:

Oleksandr Lezik

Candidate of Military Sciences Associate Professor

Docent of the Department

of Ivan Kozhedub Kharkiv National

Air Force University,

Kharkiv, Ukraine

https//orcid.org/0000-0002-7186-6683

Andriy Volkov

Chief of the Department

of Ivan Kozhedub Kharkiv National

Air Force University,

Kharkiv, Ukraine

https//orcid.org/0000-0003-4529-261X

Oleksandr Tokar

Senior Instructor

of Ivan Kozhedub Kharkiv National

Air Force University,

Kharkiv, Ukraine

https//orcid.org/0000-0003-4889-7550

Vladimir Stadnichenko

Deputy Head of the Department

of Ivan Kozhedub Kharkiv National

Air Force University,

Kharkiv, Ukraine

https//orcid.org/0000-0002-1780-9215

\section{СУЩНОСТЬ, СОДЕРЖАНИЕ И ОЦЕНКА ЭФФЕКТИВНОСТИ УПРАВЛЕНИЯ ПОДРАЗДЕЛЕНИЕМ ПРОТИВОВОЗДУШНОЙ ОБОРОНЫ СУХОПУТНЫХ ВОЙСК И ОГНЕМ В БОЮ}

А.В. Лезик, А.Ф. Волков, А.А. Токар, В.Г. Стадниченко

Рассматриваются основные вопросы относительно сущности и содержания управления, а также разработка основ оценки эффективности управления с иелью решения определенных задач. Кроме того, рассматриваются возможности системы управления и определяются основные факторы, от которых зависят возможности системы управления. Также определен критерий эффективности и разработаны предложения по повышению эффективности управления подразделением ПВО СВ и огнем в бою в различных условиях обстановки. Данные положения могут быть использованы для повышения эффективности обучения курсантов факультета, обучающихся на курсах повышения квалификачии, совершенствования учебного процесса подготовки специалистов факультета, а также качества подготовки специалистов по специальности.

Ключевые слова: управление, критерий, эффективность, подразделение ПВО СВ.

\section{ESSENCE, CONTENT AND EVALUATION OF MANAGEMENT EFFICIENCY AIR DEFENSE OF LAND FORCES AND FIRE IN BATTLE}

O. Lezik, A. Volkov, O. Tokar, V. Stadnichenko

The main issues concerning the essence and content of management are considered, as well as the development of bases for evaluating the effectiveness of management in order to solve certain tasks. In addition, the capabilities of the management system are considered and the main factors on which the capabilities of the management system depend are determined. The criterion of efficiency is also defined and the proposals on increase of efficiency of management of JI air defense unit and fire in combat in different conditions of the situation are developed. These provisions can be used to improve the effectiveness of training of cadets of the faculty and those enrolled in advanced training courses, to improve the educational process of training specialists of the faculty, as well as the quality of training of specialists in the specialty. The solution of a complex range of tasks of JI air defense units requires a coherent management system, scientific organization of management activities and the use of effective methods of work of the command and staffs. It should be borne in mind that equipping JI air defense units with technical means and automated control systems not only increases efficiency, but also complicates the control system as a whole, as well as its individual elements. And this, in turn, requires strict consideration of economic, social and psychological factors in determining the methods of functioning of the management system. The set of problems and issues that determine the state of the management system of JI air defense units, necessitates the presence of a special scientific apparatus that allows to assess the effectiveness of combat management (actions) of JI air defense units and identify ways to improve it. In other words, such an apparatus must produce scientifically sound practical recommendations based on objective laws (laws) using the latest advances in various related sciences. The solution of any of the control tasks performed in the control loop is ultimately reduced to three positions of the control cycle. The implementation of such important requirements as efficiency and quality of management at all stages of the management cycle should be assessed comprehensively, but taking into account the priority of each of these requirements. Thus, we can conclude that the capabilities of the control system is most appropriate to assess from the standpoint of the implementation of the cycle. Since the control system consists of subsystems (controls, control points, ACS, communications and other special subsystems), to determine the capabilities of the control system as a whole it is necessary to be able to determine the capabilities of its subsystems.

Keywords: management, criterion, efficiency, JI air defense unit. 